\title{
Pseudomonas pseudoalcaligenes
}

National Cancer Institute

\section{Source}

National Cancer Institute. Pseudomonas pseudoalcaligenes. NCI Thesaurus. Code C86704.

A species of aerobic, Gram negative, rod shaped bacteria in the phylum Proteobacteria.

This species is motile, non spore forming and able to use cyanide as a source of nitrogen. P. pseudoalcaligenes is a plant pathogen but may also be used for bioremediation. 